\title{
Бактерии в гифосфере Phytophthora infestans и Alternaria alternata на картофеле
}

\author{
Bacteria in Phytophthora infestans and Alternaria alternata hyphosphaere on potato
}

Смирнов А.Н., Васильченко В.В., Воробьева К.С.

\section{Аннотация}

Фитофтороз и альтернариоз, вызываемые фитопатогенами Phytophthora infestans (Mont.) de Bary и Alternaria alternata (Fr.) Keissl., - опаснейшие болезни картофеля и томата. Бактериозы картофеля другая опасная проблема как картофеля и томата, так и других с.-х. культур. Нередко возбудители бактериозов, особенно пектолитические бактерии, присутствуют на пораженных растениях вместе с фитопатогенными псевдогрибами и грибами, в том числе с Ph. infestans и A. alternata. Цель исследования - оценить присутствие бактерий в гифосфере Phytophthora infestans и Alternaria alternata, а также влияние бактерий на характеристики Ph. infestans и A. alternata. Лабораторные исследования проводили в лаборатории сектора фитопатологии кафедры защиты растений в 2016-2019 годах. Использовали изоляты Ph. infestans T-9, IO-37, 161, A. alternata Д12 из коллекций МГУ имени М. В. Ломоносова и РГАУ-МСХА имени К. А. Тимирязева. Заражение дисков клубней картофеля сортов Жуковский ранний, Ред Скарлетт, Сарпо Мира, Луговской, Удача проводили в марте 2016 года на фоне потепления погодных условий, температура в лаборатории достигала $25^{\circ} \mathrm{C}$. Наличие бактерий в мицелиях исследуемых штаммов $P h$. infestans, выращиваемых на овсяном агаре, проверялили посредством световой и электронной микроскопии, а также путем смывов с мицелиев и высевом на специальные питательные среды King B и YDS. В результате исследований доказано наличие пектолитических бактерий в гифосфере Ph. infestans и A. alternata. При наличии бактерий доказаны лизис и изменения морфологии Ph. infestans и конкурентная экспрессия по локусам глюкозо-6 фосфат изомеразы (Gpi-1) и малатдегидрогеназы (Mdh-2). Инокуляция клубневых дисков четырех copтов картофеля Жуковский ранний, Ред Скарлет, Сарпо Мира и Удача суспензиями патогенов на фоне повышенной температуры выявили значительное развитие бактериозов уже на первые сутки инкубации. Только на сорте Луговской развитие данные симптомов было в значительной степени подавлено. Мицелии Ph. infestans, A. alternata и пектолитические бактерии их гифосферы образуют на картофеле единый и достаточно стабильный патокомплекс с достаточно сложными взаимосвязями, которые предстоит изучать. Этот патокомплекс способен создать напряженный комбинированный инфекционный фон на картофеле, который в ряде случаев способен представлять для него существенную опасность.

Ключевые слова: фитофтороз картофеля, альтернариоз картофеля, Phytophthora infestans, Alternaria alternata, пектолитические бактерии.

Для цитирования: Смирнов А.Н., Васильченко В.В., Воробьева К.С. Бактерии в гифосфере Phytophthora infestans и Alternaria alternata на картофеле // Картофель и овощи. 2020. №3. С. 24-27. https://doi.org/ 0.25630/PAV.2020.80.55.003

\section{Smirnov A.N., Vasil'chenko V.V., Vorob'eva K.S.}

\section{Abstract}

Late blight and early blight caused with phytopathogens Phytophthora infestans (Mont.) de Bary and Alternaria alternata ( $\mathrm{Fr}$.) Keissl. are the dangerous diseases of potato and tomato. Bacteria are connected to the other dangerous problems of both potato and tomato, and other crops. Often bacteria especially pectolytic bacteria occur on affected plants with phytopathogeneous pseudofungi and fungi - with $P h$. infestans и $A$. alternata as well. Objective of our investigation is an estimation of bacterial occurrence in Ph. infestans and $A$. alternata hyphosphaere as well as influence of bacteria on the $P h$. infestans and $A$. alternate properties. Laboratory investigations were conducted at phytopathology branch of department of plant protection of RSAU-MTAA in 2016-2019. Ph. infestans isolates T-9, IO-37, 161, A. alternata isolate D12 of MSU and RSAU-MTAA were investigated. Tuber disc inoculation of potato cultivars Zhukovskiy ranniy, Red Scarlett, Sarpo Mira, Lugovskoy and Udacha was done in 2016 at the temperature about $25^{\circ} \mathrm{C}$. Checking bacterial occurrence was done in Ph. infestans mycelia grown at oatmeal agar by means of light and electronic microscopy as well as with transferring on special selective media King B and YDS. As a result, occurrence of pectolytic bacteria was proved to be in Ph. infestans and A. alternata hyphosphaere. At bacterial occurrence $P h$. infestans lysis and morphological deviations as well as competitive expression at the loci of Glucose 6 Phosphate Isomerase (Gpi-1) and Malate Dehydrogenase (Mdh-2) are proved to be developed. Inoculation of potato tuber discs of five cultivars Zhukovskiy ranniy, Red Scarlett, Sarpo Mira and Udacha with suspensions of pathogens at increased temperature revealed essential bacterial development at increased temperature during already first day of incubation. Manifestation of these symptoms was significantly suppressed only on cultivar Lugovskoy. Ph. infestans and $A$. alternata mycelia as well as pectolytic bacteria of their hyphosphaere form on potato unique and stable pathocomplex with complicated interconnections which should be studied as quickly as possible. This pathocomplex provides strong combined infective phone on potato which is able to be essentially dangerous for this crop.

Key words: potato late blight, potato early blight, Phytophthora infestans, Alternaria alternata, pectolytic bacteria.

For citing: Smirnov A.N., Vasil'chenko V.V., Vorob'eva K.S. Bacteria in Phytophthora infestans and Alternaria alternata hyphosphaere on potato. Potato and vegetables. 2020. No3. Pp. 24-27. https://doi.org/ 0.25630/PAV.2020.80.55.003 (In Russ.)
$\Phi$ итофтороз и альтернариоз, вызываемые фитопатогенами Phytophthora infestans (Mont.) de Bary и Alternaria alternata (Fr.) Keissl.,- опаснейшие болезни картофеля и томата. Определение потенциалов оомицета Ph. infestans и гриба A. alternata, стратегий размножения и потенциала жизнеспо- собности очень важно для определения рисков и разработки современных способов защиты от них, ограничения численности данных опасных патогенов на картофеле [1, 2, 3, 4].

Бактериозы картофеля - другая опасная проблема как этой, так и других с.- х. культур $[5,6]$. Нередко возбудители бактериозов, особенно пектолитические бактерии, присутствуют на пораженных растениях с фитопатогенными псевдогрибами и грибами, в том числе с Ph. infestans и A. alternata. Возможность сосуществования, взаимовлияния и взаимодействия между ними - принципиальный актуальный вопрос современной фи- 

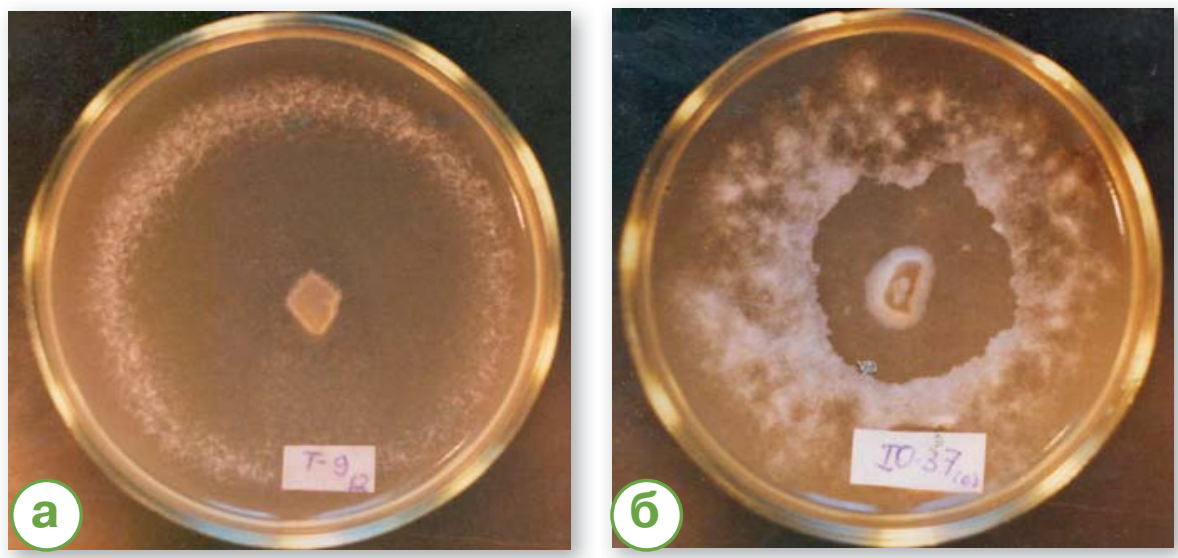

Pис. 1. Центробежный лизис колонии P. infestans на овсяном агаре (штамм T9) в центральной части, а - с ровным краем; б - с неровным краем

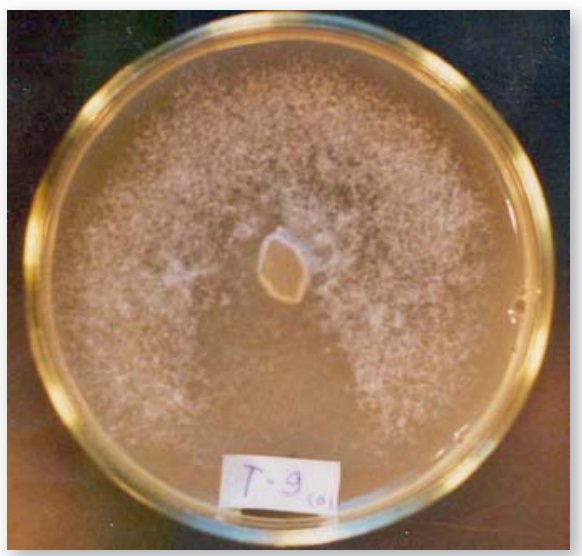

Рис. 2. Секторальный лизис колонии $P$. infestans на овсяном агаре (штамм T9)

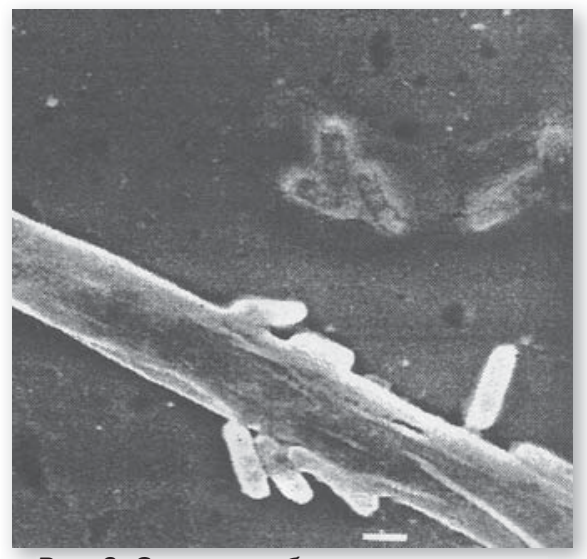

Рис. 3. Скопления бактериальных клеток, локализующихся на гифе $P$ infestans. Масштаб - 1 нм. Электронная микроскопия

топатологии, требующий разностороннего изучения.

Цель исследования - оценить присутствие бактерий в гифосфеpe $P h$. infestans и A. alternata, а также влияние бактерий на характеристики Ph. infestans и A. alternata.

\section{Условия, материалы и методы} исследований

Мицелии колоний Ph. infestans и A. alternata изучали в лаборатории сектора фитопатологии кафедры защиты растений в 2016-2019 годах. Использовали изоляты Ph. infestans Т-9, IO-37, 161, A. alternata Д12 из коллекций МГУ имени М. В. Ломоносова и РГАУ-МСХА имени К. А. Тимирязева. Диски клубней картофеля сортов Жуковский ранний, Ред Скарлетт, Сарпо Мира, Луговской, Удача заражали по стандартной методике [7] в марте 2016 года на фоне потепления погодных условий, когда температура в лаборатории достигала $25^{\circ} \mathrm{C}$. Проводили электрофорез изоферментов фосфоглюкоизомеразы (Gpi1) и малатдегидрогеназы. [8].

Наличие бактерий в мицелиях исследуемых штаммов Ph. infestans, выращиваемых на овсяном агаре, проверяли посредством световой и электронной микроскопии, а также путем смывов с мицелиев и высева на специальные питательные среды King В и YDS [8].

\section{Результаты исследований}

При развитии колоний исследуемых штаммов Ph. infestans обнаруживали прогрессирование центробежного лизиса в центральной части (рис. 1) и секторов (рис. 2) колоний патогена.

На мицелиях Ph. infestans в зоне гифосферы обнаружили скопления бактериальных клеток, локализующихся на и внутри гиф (рис. 3), иногда образующих вдоль гиф плотные чехлы из скоплений бактерий и продуктов их жизнедеятельности (рис. 4).

Всего было изучено 70 колоний исследуемых штаммов Ph. infestans на наличие лизиса, сопровождающегося различными морфологическими отклонениями мицелия и зооспоран- гиев и встречаемости бактерий в гифосфере. Коэффициент корреляции r между развитием лизиса и встречаемостью бактерий в гифосфере оо-

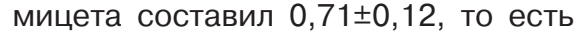
между этими проявлениями установлена хорошая взаимосвязь.

Для 78 полевых образцов листьев картофеля из Московской области, пораженных фитофторозом, коэффициент корреляции $r$ между лизисом с морфологическими отклонениями мицелия $P h$. infestans и встречаемостью бактерий в гифосфере патогена составил $0,73 \pm 0,10$. Между этими проявлениями также установлена хорошая взаимосвязь [8].

Отметим, что лизис колоний исследуемых штаммов Ph. infestans в большей степени проявлялся в стареющих мицелиях, а также по мере повышения температуры инкубации мицелиев до 25-26 C. Для исследуемого изолята $A$. alternata, в гифосфере которого также обнаруживали бактерии, выявили такие же тенденции.

В результате электрофоретического исследования генопродуктовизоферментов глюкозо-6 фосфат изомеразы (локус Gpi-1) и малатдегидрогеназы (локусы Mdh-1 и Mdh-2) исследуемых штаммов Ph. infestans, в гифосфере которых присутствовали бактерии, обнаружили признаки конкурентной экспрессии генов $\mathrm{Ph}$. infestans и бактерий.

При исследовании глюкозо-6 фосфат изомеразы (пять образцов) в образце 1 встречаемость бактерий гифосферы была значительной, в образце 3 - умеренной, в образце 2 на низком уровне. Соответственно, в образце 1 выявлен преимущественно генопродукт, соответствующий контаминированной (бактериальной) ДНК, в образце 3- генопродукты и Ph. infestans, и бактерий, в образце 2 - только генопродукт $P h$. infestans (рис. 5). В двух образцах между образцами 2 и 3 экспрессивная активность данного гена была на низком уровне.

При исследовании малатдегидрогеназы (пять образцов, нумерация на геле - слева направо) в образце 1 встречаемость бактерий гифосферы была значительной, в образце 3 - умеренной, в образцах 2, 4, 5 - на низком уровне. Ген Mdh-1 во всех образцах работал очень активно, его конкурентное ингибирование не наблюдали. В образце 1 выявлен преимущественно генопродукт, соответствующий контаминированной (бакте- 


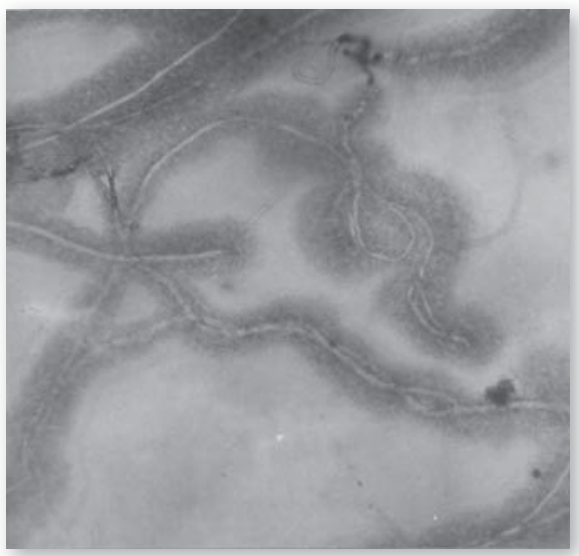

Рис. 4. Скопления бактериальных клеток в виде плотных чехлов, развивающихся вдоль гиф P. infestans. Масштаб - 100 нм. Световая микроскопия

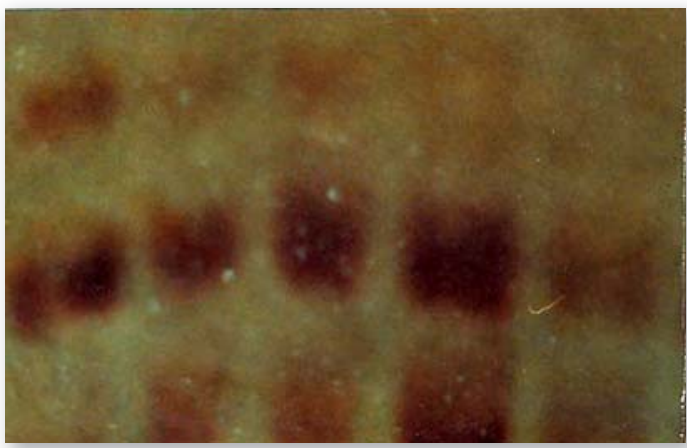

Рис. 6. Изоферментные генопродукты по локусам Mdh. Нижний локус - P. infestans (Mdh-2), средний локус - P. infestans (Mdh-1), верхний локус - контаминанатная ДНК. Объяснение в тексте.

риальной) ДНК, в образце 3 - генопродукты и Ph. infestans (локус $M d h-2)$, и бактерий, в образце 2, 4 и 5 - только генопродукт Ph. infestans (локус Mdh-2), контаминантный генопродукт - на остаточном уровне (рис. 6).

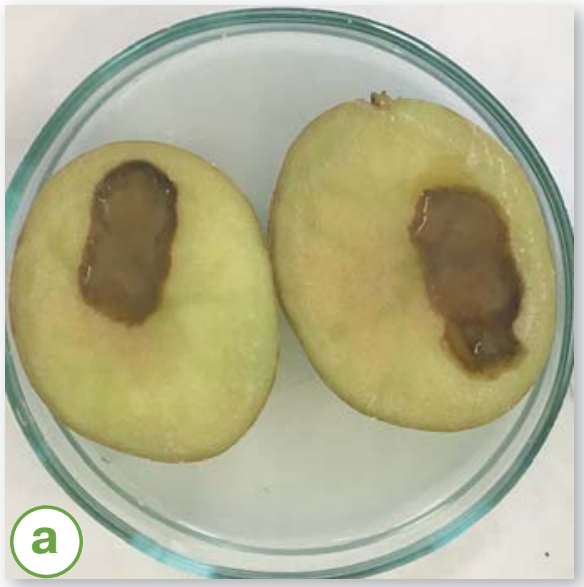

\section{1 2}

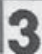

Рис. 5. Изоферментные генопродукты по локусу Gpi-1. Нижний локус - P. infestans, верхний локус - контаминанатная ДНК. Объяснение в тексте

Смывы бактерий на специальные питательные среды вполне подтвердили результаты визуальной индикации бактерий посредством микроскопии, на обеих диагностических средах выделили значительное количество колоний.

Инокуляция клубневых дисков пяти сортов картофеля Жуковский ранний, Ред Скарлетт, Сарпо Мира и Удача суспензиями патогенов на фоне повышенной температуры выявили значительное развитие бактериозов уже на первые сутки инкубации (рис. 7). Только на сорте Луговской развитие данные симптомов было в значительной степени подавлено. В контрольных вариантах, когда на клубневые диски наносили воду, развития бактериозов не наблюдали. Такое развитие бактериозов не было характерно при заражениях картофельных клубневых дисков при аналогичных проводимых опытах $[7,8]$. Возможно, это связано с каким-либо изменением сезонных биоритмов патогенов, спрово-

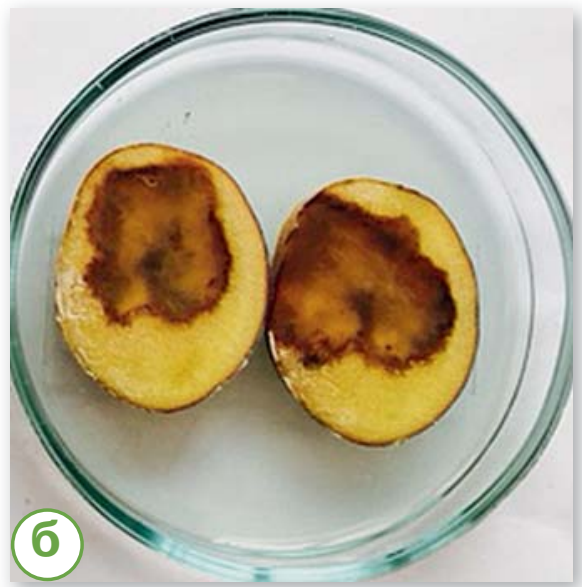

цированных в том числе повышением температуры инкубации.

Предварительная диагностика бактерий с использованием специальных селективных сред показала, что часть исследованных колоний бактерий соответствовала роду Pseudomonas, часть роду Bacillus. Определенно, в гифосфере могли случайно оказаться и другие бактерии. Также очень вероятно, что большинство исследуемых бактерий обладали пектолитической активностью и могли относится к родовому бактериальному комплексу: Erwinia, Dickeya, Pectobacterium.

Полученные результаты име ют три возможных объяснения. Во-первых, пектолитические бактерии способны находиться в гифосфере фитопатогенных псевдогрибов и грибов, попадать с ними на картофель и вызывать его гниль. Во-вторых, Ph. infestans и A. alternata, возможно в определенных условиях способны провоцировать к значительному развитию пектолитические бактерии, некоторые из которых в качестве фона способны находиться на и в клубнях картофеля (А. Н. Игнатов, личное сообщение). Если

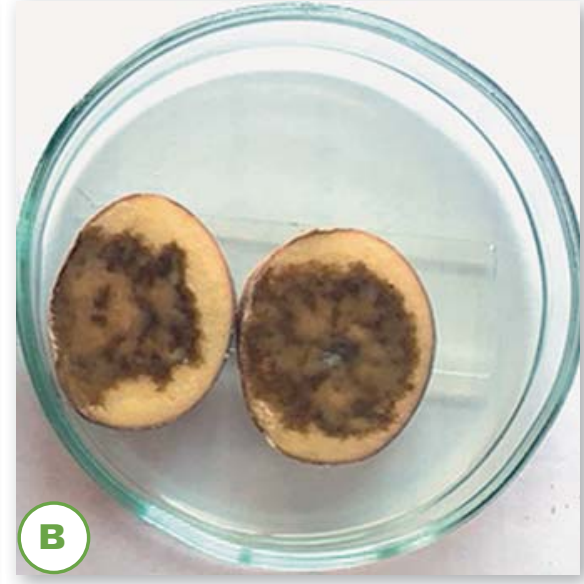

Рис. 7. Развитие бактериальных симптомов на клубневых дисках: а - сорта Удача на вторые сутки после инокуляции суспензией зооспорангиев P. infestans; б - сорта Ред Скарлетт на третьи сутки после инокуляции суспензией конидий A. alternata; в - сорта Ред Скарлетт на вторые сутки после инокуляции смешанной суспензией зооспорангиев P. infestans и конидий A. alternata 
это так, то механизм данного явления пока непонятен. Наконец, в-третьих, пектолитические бактерии сами способны вызвать данные симптомы. Однако третьему объяснению противоречит отсутствие развития бактериальных симптомов в контролях (инокуляция дисков клубней картофеля водой) и развитие бактериальных гнилей и экссудатов только в месте инокуляции суспензиями Ph. infestans и A. alternata.

Полного подавления развития патогенов в проведенных экспериментах не наблюдали. Поэтому едва ли данные бактерии удасться использовать в биозащите карто- феля от патогенов грибной и псевдогрибной природы. Наиболее вероятно, что пектолитические бактерии способны к совместному развитию и длительному сосуществованию с мицелиями фитопатогенных грибов и псевдогрибов на картофеле. На это указывает факт исходного выделения изолятов $\mathrm{Ph}$. infestans и A. alternata из тканей картофеля, где определенно есть некоторое количество пектолитических бактерий. Также на это указывает факт, что развитие псевдогрибов и грибов на тканях картофеля всегда замещается значительным развитием бактерий.

\section{Выводы}

Phytophthora infestans и Alternaria alternata с одной стороны, и пектолитические бактерии с другой стороны образуют на картофеле единый и достаточно стабильный патокомплекс с достаточно сложными взаимосвязями, которые предстоит изучать. Этот патокомплекс способен создать напряженный комбинированный инфекционный фон на картофеле, который в ряде случаев способен представлять для него существенную опасность.

Авторы благодарны В.И. Глазко, Ф.С. - У. Джалилову и А.Н. Игнатову за консультации при выполнении и написании данной работы.

\section{Библиографический список}

1.Прикладное значение определения репродуктивного потенциала и агрессивности грибных и псевдогрибных патогенов картофеля и томата / А.Н. Смирнов, Е.С. Приходько, В.В. Васильченко, В.П. Хохлов, А.А. Сухоруков, С.А. Кузнецов // Картофель и овощи. 2019. №6. С. 18-23. https://doi.org/10.25630/PAV.2019.71.33.005

2.Козловский Б.Е., Филиппов А.В. Альтернариоз картофеля // Картофель и овощи. 2007. № 4. С. 31.

3.Фитофтороз и альтернариоз картофеля и томата при аномальных погодных условиях в Московской области / A. Золфагари, В.В. Антоненко, Д.В. Зайцев, А.А. Игнатенкова, А.Г. Мамонов, Р.В. Пенкин, А.Ю. Поштаренко, А.Н. Смирнов // Защита и карантин растений. 2011 №4. С. 40-42.

4.Смирнов А.Н., Кузнецов С.А. Определение стратегий размножения и жизнеспособности полевых популяций Phytophthora infestans // Защита и карантин растений. 2006. №3. С. 20-23.

5.Лазарев А. М. Перечень научных литературных источников по исследованию бактериозов растений и биологических свойств их возбудителей. СПб: ВИР, 2019. 27 с.

6.Динамика видового состава патогенов картофеля в Европейской части РФ./ А.Н. Игнатов, Ю.С. Панычева, М.В. Воронина, Д.М. Васильев, Ф.С. Джалилов // Картофель и овощи. 2019. №9. С. 28-32. https://doi.org/10.25630/ PAV.2019.57.62.003

7.Преодоление сортовой устойчивости клубней картофеля к возбудителям основных болезней картофеля в зависимости от изменений микологических параметров патогенов / В.В. Васильченко, А.А. Адамов, О.А. Жигачев, А.Н. Смирнов // Аграрная наука. 2019. № 53. С. 69-72. https://doi. org/10.32634/0869-8155-2019-326-3-69-72

8.Смирнов А.Н. Популяционная структура фитопатогенного гриба Phytophthora infestans (Mont) de Bary в Московской области в 1991-1996 годах: дисс. канд. биол. наук. М: МГУ, 1996. 209 c.

\section{References}

1.Applied value of determining the reproductive potential and aggressiveness of fungal and pseudo-fungal pathogens of potatoes and tomatoes. A.N. Smirnov, E.S. Prikhod'ko, V.V. Vasilchenko, V.P. Khokhlov, A.A. Sukhorukov, S.A. Kuznetsov. Potato and vegetables. 2019. No. 6. Pp. 18-23 (In Russ.). https://doi.org/10.25630/ PAV.2019.71.33.005

2.Kozlovskii B.E., Filippov A.V. Early blight of potatoes. Potato and vegetables. 2007. No.4. P. 31 (In Russ.).

3.Phytophthorosis and alternariosis of potatoes and tomatoes under abnormal weather conditions in the Moscow region. A. Zolfagari, V.V. Antonenko, D.V. Zaitsev, A.A. Ignatenkova, A.G. Mamonov, R.V. Penkin, A.Yu. Poshtarenko, A.N. Smirnov. Plant protection and quarantine. 2011. No. 4. Pp. 40-42 (In Russ.).

4.Smirnov A.N., Kuznetsov S.A. Determination of strategies of reproduction and viability of field populations of Phytophthora infestans. Plant protection and quarantine. 2006. No. 3. Pp. 20-23 (In Russ.).

5.Lazarev A.M. List of scientific literature on the study of bacterial diseases of plants and biological properties of their agents. St. Petersburg: VIR, 2019. 27 p. (In Russ.).

6.Dynamics of the species composition of potato pathogens in the European part of the Russian Federation. A.N. Ignatov, Y.S. Panycheva, M.V. Voronin, D.M. Vasil'ev, F.S. Dzhalilov. Potato and vegetables. 2019. No. 9. Pp. 28-32 (In Russ.). https://doi. org/10.25630/PAV.2019.57.62.003

7.Overcoming varietal resistance of potato tubers to pathogens of the main potato diseases depending on changes in mycological parameters of pathogens. Vasilchenko V.V., Adamov A.A., Zhigachev O.A., Smirnov A.N. Agrarian science. 2019. No. 53. Pp. 69-72 (In Russ.). https://doi.org/10.32634/0869-8155-2019-326-3-69-72

8.Smirnov A.N. Population structure of the phytopathogenic fungus Phytophthora infestans (Mont) de Bary in the Moscow region in 1991-1996: Diss. Cand. Biol. sciences. Moscow: Moscow State University, 1996. 209 p. (In Russ.).

\section{Об авторах}

Смирнов Алексей Николаевич, доктор биол. наук, профессор сектора фитопатологии кафедры защиты растений, ФГБОУ ВО РГАУ-МСХА имени К.А. Тимирязева, Г. н. с. отдела интенсивного земледелия, Владимирский НИИСХ. E-mail: asmirnov@rgau-msha.ru

Васильченко Виктория Владимировна, аспирант сектора фитопатологии кафедры защиты растений, ФГБОУ ВО РГАУ-МСХА имени К.А. Тимирязева. E-mail vasilcenkoviktoria16@gmail.com

Воробьева Ксения Сергеевна, магистр сектора фитопатологии кафедры защиты растений, ФГБОУ ВО РГАУ-МСХА имени К.А. Тимирязева

\section{Author details}

Smirnov A.N., Doctor Sci. (Biol.), professor of the department of plant protection, branch Phytopathology, Russian State Agrarian University - Moscow Agricultural Academy named after Timiryazev, chief research fellow of the department of intensive agriculture, Vladimir Research Institute of Agriculture. E-mail: asmirnov@rgau-msha.ru

Vasilchenko V.V., postgraduate student of the branch Phytopathology, the department of plant protection, Russian State Agrarian University - Moscow Agricultural Academy named after Timiryazev. E-mail: vasilcenkoviktoria16@gmail.com

Vorob'eva K.S., master of the branch Phytopathology, the department of plant protection, Russian State Agrarian University Moscow Agricultural Academy named after Timiryazev 